
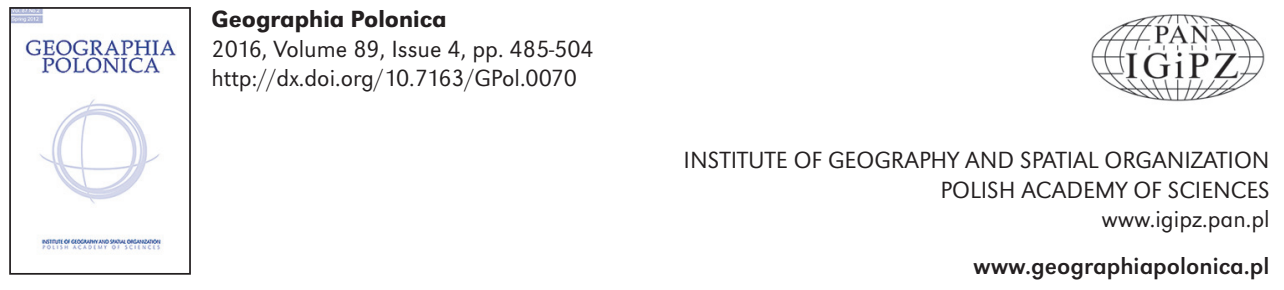

\title{
TRANSPORT MEANS AND ORGANISED TOURISM: EMPIRICAL EVIDENCE FROM POLAND
}

\author{
Zbigniew Taylor • Ariel Ciechański \\ Institute of Geography and Spatial Organisation \\ Polish Academy of Sciences \\ Twarda 51/55, 00-818 Warsaw: Poland \\ e-mails: z.taylor@twarda.pan.pl・ariel@twarda.pan.pl
}

\begin{abstract}
This paper has sought to give some insights into the means of transport used by the 38 largest tour operators seated in Poland. The research is based on in-depth analysis and uses data from a number of tourism and transport sources. Results indicate a great concentration of the servicing of organised tourist traffic within a relatively small number of wholesalers. Basically, the effects of air carriers to date are hardly to be overestimated, and this is especially true of an assessment of recent developments as regards charter flights from/ to Poland. Coaches play a much lesser role in the servicing of organised mass tourist traffic, while other means of transport (cruise ships, railways) are used only occasionally. Overall, the analysis carried out characterises the country's leisure travel market as one which is only at the early stages of maturity.
\end{abstract}

\section{Key words}

transport for tourism - passenger carriers - airlines $\cdot$ coaches $\bullet$ cruise ships $\bullet$ railways $\bullet$ tour operators $\bullet$ package holidays $\bullet$ tourism-exporting economy

\section{Introduction}

Existing Polish literature both economic and geographical has tended to focus either on transport, or on tourism. Despite an increase in the number of scientific papers in the relevant literature, there remain no detailed works on the cooperation between transport and tourism, this undoubtedly leaving the existing situation as an unsatisfactory one. Meanwhile, interdependences between transport and tourism are present on many levels, not least because transport is coresponsible for the development of tourism, while also joining it in the improvement of the organisation of tourist traffic, and - obviously - in the provision of tourist carriage. This paper is devoted to the carriage companies involved in the servicing of organised (collective, mass) tourist traffic in Poland, a subject that is relatively less well-known in the literature (Taylor \& Ciechański 2014). 
The basic goals of this paper have been as follows:

(1) to better understand which transport companies are involved in servicing Polish organised tourist traffic; and

(2) to identify and comprehend the relationships between means of transport used in the servicing of tourist traffic and types of tourism.

In the research we apply various measures with a view to characterising the tour operators as well as the carriers, especially air carriers (e.g. number of passengers served, size of fleet and tour operators served). In similar vein, detailed data have been collected on road carriers and tourist agencies cooperating with them.

The paper is organised as follows. Section 2 briefly reviews the literature. Section 3 describes the data used and provides details on the methodology, while Section 4 contains brief characterisations of tour operators and types of carrier. The main part of the paper is Section 5, which presents an up-to-date geographical analysis of relevant passenger carriers: scheduled and charter airlines, coaches, cruise ships and railways. Finally, conclusions are reached in Section 6.

\section{Literature review}

A good, in-depth characterisation of tourist agencies, including tour operators, functioning on the Polish tourist market is provided in the publications of Konieczna-Domańska (2008) and Szymańska (2009), respectively. The former offers a thorough and systematic presentation of the activity of travel agencies against a broad economic and theoretical background, while the latter is of much more utilitarian character. For the purposes of this paper, however, a source of greater interest is a consideration of cooperation between carriers and travel agencies in a historical perspective, as presented by Konieczna-Domańska (2008).

Tourism is inevitably connected with the movement of human beings in space. The meeting of such needs implies a change of place of stay, and, therefore, a generated demand for transport. It is estimated that tourism in Europe is responsible for 15 to $20 \%$ of passenger-km accounted for by surface transport, and in air transport this share is much greater (Peteers et al. 2007). This is also the case for Poland, where in the years after 1990 it has been possible to observe great growth in tourist traffic, domestic as well as international.

In relation to the supply side of tourism transport, Hall distinguishes four general functions: "(1) linking the source market with the host destination; (2) providing mobility and access within a destination area/region/country; (3) providing mobility and access within an actual tourism attraction; and (4) facilitating travel along a recreational route, where both the transport form and nature of the route may combine or act singly to provide the tourism experience" (Hall 2008: 199). We will focus on the first function of transport, while regarding the others as of secondary, if not even marginal, importance to us.

Wheatcroft (1998) analyses the global relationship between the airline industry and tourism, seeing this as a mixture of technological factors, market pressures and regulatory policies, while Mansfeld (1990) provides an overview of spatial patterns characterising international tourist flows over the long term. Hall (1999) explores two sets of conceptual issues at the interface of transport and tourism: (1) transport as a culture gatekeeper to hosttourist interaction; and (2) the role of tourist mobility at the local level, and its impact on inequality and externality effects. The first issue is in fact a borrowing of loannides's concept of tour operators as gatekeepers of tourism (loannides 1998).

Using a social representation approach, Dickinson and Dickinson (2006) explore the multiplicity of social realities underpinning peoples' attitudes to transport tourism, and their subsequent behaviour. In a similar vein, Becken (2005) analyses the travel patterns characterising coach tours to account for potential differences between cultures of origin. Her research demonstrates that it is useful 
to segment coach tours by different cultures of origin when assessing indicators of tourist transport sustainability.

Within the context of this paper, many studies have analysed transport, especially aviation, albeit without any special reference to tourism (e.g. Panasiuk \& Pluciński 2008; Pijet-Migoń 2012). Prideaux (2000) identifies the significance of the transport system in destination development, concluding that those without airport facilities are largely restricted to markets accessible by car, while air travel is a key element in the winning of new markets beyond the reasonable reach of a car. Dobruszkes (2009) analyses how European low-cost carriers have adapted and developed their networks to the CEECs as a result of the liberalisation of air space, offering new opportunities for servicing airlines. East-West flights were numerous in 2008 but intra-West services remained largely dominant (Dobruszkes 2009).

The last several years have also brought substantial books on aviation. For example, in a monograph, Graham et al. (2008) discuss the implications of the aviation industry for leisure travel on a worldwide scale, while Bowen (2010) presents the technological development of aviation, competition among aircraft manufacturers, the deregulation and privatisation of the airline industry, the articulation of passenger and cargo services, and problems facing airports - all from a geographical point of view. In similar vein, Doganis (2006, 2010) analyses the effect of continued liberalisation and 'open skies' policies, the need to cut labour costs, the impact of alliances and consolidation, the growing threat of lowcost carriers and the problems faced by stateowned airlines. In turn, Wensveen (2011) looks at air transportation from a management perspective, while the volume edited by Gross and Lück (2013) provides an overview of the development of LCCs around the globe, discussing regional aviation profiles, the background and growth of LCCs on respective markets, recent market trends and examples of best practice.

Cruising has also become the theme of many larger publications. For example,
Dickinson and Vladimir (2008) examine all aspects of the modern cruise industry, describe revolutionary management, marketing and sales techniques, all under the book's very telling title of Selling the Sea. Cruise ship tourism seen from various perspectives is in turn the theme of a collective work edited by Dowling (2006). World cruising routes are also looked at by the literature (e.g. Cornell 2008). A common feature of all the publications referred to is their very practical character.

In summary, literature reviewed shows a substantial research gap existing at the fringe of carriers and tour operators. This should be partly filled in the paper in the context of Polish situation.

\section{Sources, methods of collection and data processing}

Despite the existence of at least several institutions involved in the collection of data on companies, there is no single proper and reliable base on tour operators and carriers - a fact that has necessitated the creation of four databases by the authors.

The basic sources in the creation of a homogeneous base of tour operators have been single items of information on enterprises included in Hoppenstedt Bonnier Information Polska (HBI). On the basis of these a list of 398 enterprises with main and additional ${ }^{1}$ activities described by code 6330 of the European Classification of Activities (Activity of tourist agencies, pilots and tour guides; remaining tourist activity) and with annual turnover above 1 million zloties ${ }^{2}$ has been created. This list was then cut to exclude 20 tour operators going bankrupt or being closed down in the years 2010-2012, checked in the Central Register of Tourist Agencies and Tourist Brokers (Centralna Ewidencja Organizatorów Turystyki i Pośredników Turystycznych, abbreviated later to CEOTiPT) and compared with reports

\footnotetext{
1 Some entities, despite actually being active in organising tourism, may be registered under a completely different category of activity.

$21 € \approx 4.0-4.3$ zloties.
} 
in the periodical Wiadomości Turystyczne (Touroperatorzy 2012 and Touroperatorzy 2013).

The final list consists of the largest tour operators (38 entities in total) with annual turnover from the organisation of tourism exceeding 10 million zloties (as of 2012). The list has been updated and supplemented with certain missing information on the basis of the aforementioned Touroperatorzy reports, as well as data and information from the National Registry (Krajowy Rejestr Sadowy, KRS). The latter is made available by the firm InfoVeriti (www.infoveriti.pl). Annual reports of larger companies and official websites of entities involved have also been taken into account.

The second and third databases concern Polish and foreign air carriers in the service of Polish tour operators. While the second base consists of network (scheduled) carriers, the third includes charter carriers. In each case, the basis has been created by lists of the 25 most important air carriers providing flights from/ to Poland, network or charter, respectively, published by the Civil Aviation Authority (Urzad Lotnictwa Cywilnego, ULC). Catalogues and websites of tour operators cooperating with selected carriers have been used to provide supplementary information. In the case of a lack of official data, connections between the tour operator researched and carriers have been looked for by searching for key words (a combination of the tour operator's name and the means of transport, or names of carriers) in the Polish and English languages. In this case commonly-used Internet browsers have been used. Information on air carriers has been supplemented using data from the Polish-registered firm InfoVeriti, and from press materials, websites and annual reports of entities (registered in Poland or abroad). In the case of certain network carriers, cooperating tour operators could not be found and/ or confirmed. Nevertheless, both databases, despite featuring a relatively small number of air carriers (25 in each) embrace the overwhelming majority of passengers served at Polish airports. In the case of scheduled traffic the proportion reaches $98.7 \%$, while in the case of charter traffic it is $96.8 \%$. Other carriers, despite being present on the market in large numbers, participate in carriage at minimum levels only.

Finally, the fourth, smallest, database takes in the largest Polish road carriers engaging in the transport of tourists via feeder lines (four entities) and long-distance coach services (the remaining entities) for tour operators. Some tour operators possess fleets of coaches of their own. The basis for this has been created using catalogues and websites of tour operators. As in the case of the airlines, information on coach carriers has been supplemented by data from the firm InfoVeriti, press information, webpages and annual reports of given companies.

\section{General characteristics of tour operators and carriers}

The authors' database extends to just 1.2\% of the total number of tour operators ${ }^{3}$ and tour operators plus travel agents registered in Poland (in total 3116 entities in 2012, according to CEOTiPT). "The last several years have brought a further increase in the total number of registered tourist agencies, as the distant geographical scope of travel activates demand for brokerage services and organisation" (Konieczna-Domańska 2008: 67).

Although the database contains just 38 tour operators, it is these that are the largest and play the most important role on the Polish market for organised tourist traffic. All calculations and generalisations in this paper therefore concern these data, from which further conclusions have been drawn.

The concept of turnover helps express the commercial size of a given enterprise. Thus, turnover represents gross revenues or gross amounts due connected with the sale of tourist services by a given tour operator. If we take into account the criterion of turnover, then the

3 The product of a tour operator is a comprehensive package of services embracing transport, accommodation, catering, sightseeing, pilotage, entertainments, rent-a-car, insurance and others. 
list of the largest travel agencies registered in 2012 embraces just the 38 tour operators referred to above (with a joint turnover of 4.29 billion zloties, or more than three-quarters of the entire market). Comparisons with the previous year reveal an increase by 10 in the number of such tour operators, with some changes in ranking positions also being noted.

Tour-operator structure in terms of levels of turnover can be described as oligopolistic, in that there is a great difference in size between several large companies and the remainder. It is quite probable that the next few years will bring both further consolidation and polarisation, with small firms being incorporated into larger ones, and either disappearing from the market, or finding themselves in niches being beyond the interest of the 'giants' (Konieczna-Domańska 2008; Williams 2008).

When tour operators are considered, there is found to be a dependent linear relationship between turnover resulting from the organisation of tourist events and numbers of customers (tourists), with this taking the form:

$$
y=0.001860 x^{2}+393.667309 x
$$$$
+12465.381239
$$

where $x$ is turnover resulting from the organisation of instances of tourism,

$y$ is the number of customers of given tour operators.

The interdependence is described by a linear regression model which achieves statistical significance: correlation coefficient $r=0.980822$, and determination coefficient $r^{2}=0.96201181$.

Where characterisation of the sizes of tourist agencies is concerned, turnover would seem to be the best possible measure (rather than number of entities, customers served, or numbers employed). Foreign outward tourism is the absolute dominant in terms of the level of turnover achieved (taking some $87.7 \%$ of the total). Second place is taken by 'mixed' tourism - an offer comprising outward and inward tourism (most frequently foreign, but partly also domestic), which accounts for just $10.7 \%$, while inward tourism is responsible for just $1.6 \%$ of all turnover. Such a distribution confirms the fact that Poland is first and foremost a tourism-exporting economy, while inward tourism accounts for only a small share of overall tourist traffic. Since the bulk of turnover (and probably profit) comes from foreign outward tourism participated in by Polish citizens, all major travel agencies are extremely active in this sort of operation. Tour operators involved in foreign outward and inward tourism simultaneously have their seats in the cities of Warsaw, Poznań, Kraków and Opole. A few travel agencies also take part in domestic inward tourism (Fig. 1).

Tour operators make use of various means of transport. As Forsyth (2008: 74) writes, "Aviation is the preferred form of transport for much of tourism, especially long- haul tourism and tourism to islands. It is particularly important for international tourism". This is also the case for Poland, where the use of aeroplanes and 'various means of transport' are in similar positions when it comes to turnover resulting from the organisation of tourism $(47.7 \%$ and $48.8 \%$, respectively). However, it should be recalled that the latter category concerns usage of different means of transport, above all aeroplanes and coaches simultaneously. What is seen clearly is the more limited (3.2\%) role of coaches as a means of transport contributing to turnover arising out of the organisation of tourism. Thus, the situation as of 2012 is quite different from that observed in the 1990s, for example, when Poles participated in coach excursions to a far greater extent ${ }^{4}$.

The nature of the tourist offer is obviously connected with the means of transport employed. A wider spectrum in this regard is applied by firms with seats in Warsaw: these first and foremost use aeroplanes (accounting for $79.3 \%$ of turnover), followed by 'various means of transport' (17\%), and coaches (1.4\%). Where city of Poznań tour operators

\footnotetext{
${ }^{4}$ An absolute majority of number of tourists $(45.7 \%)$ choose aeroplanes as means of transport. If we add to this 'various means of transport' (accounting for $44.3 \%$ ) - knowing that aircraft also prevail in this category, then this means of transport is seen to be yet more dominant. In contrast, coaches are used by only $8.8 \%$ of tourists, again also partly as a category of 'various means of transport'.
} 


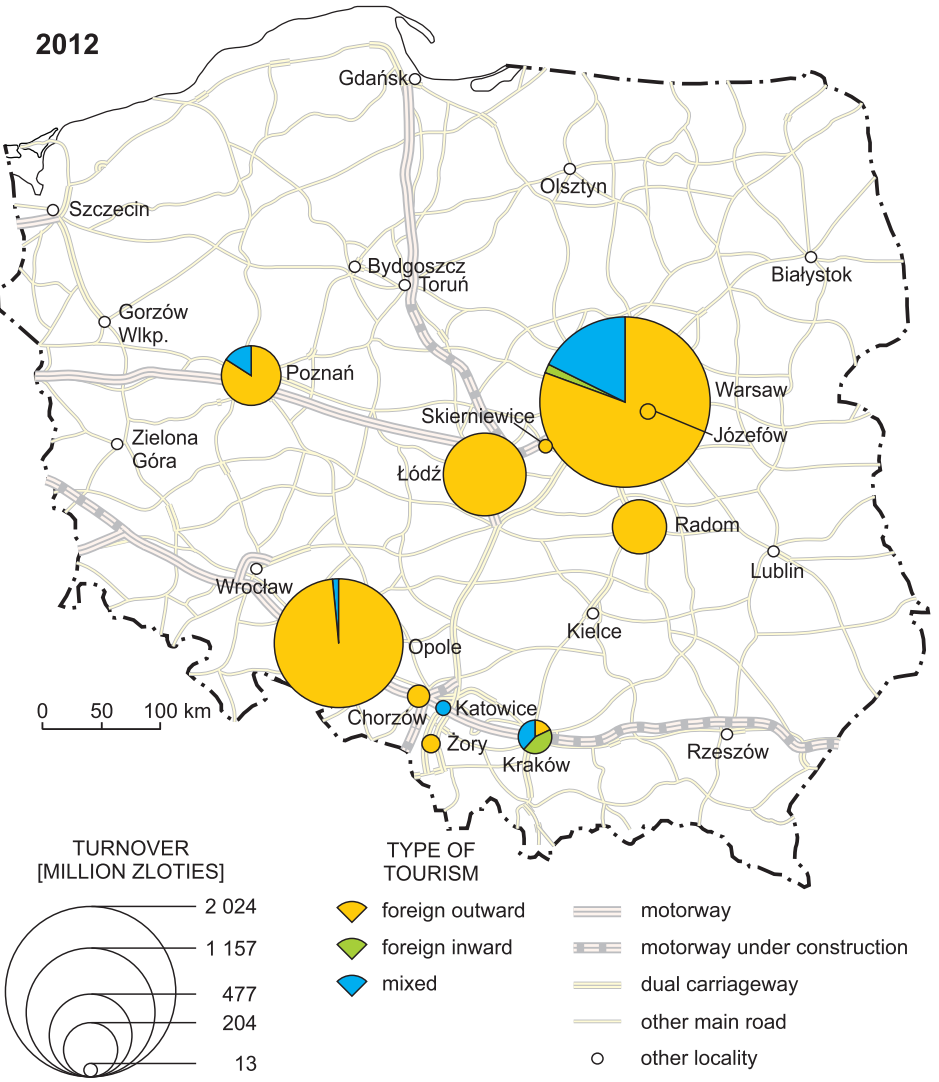

Figure 1. Tour-operator structure by type of tourism on offer and turnover from the organising of tourism

Based on: (1) Touroperatorzy Raport 2012; (2) Touroperatorzy Raport 2013; (3) www.infoveriti.pl; (4) websites of tour-operators.

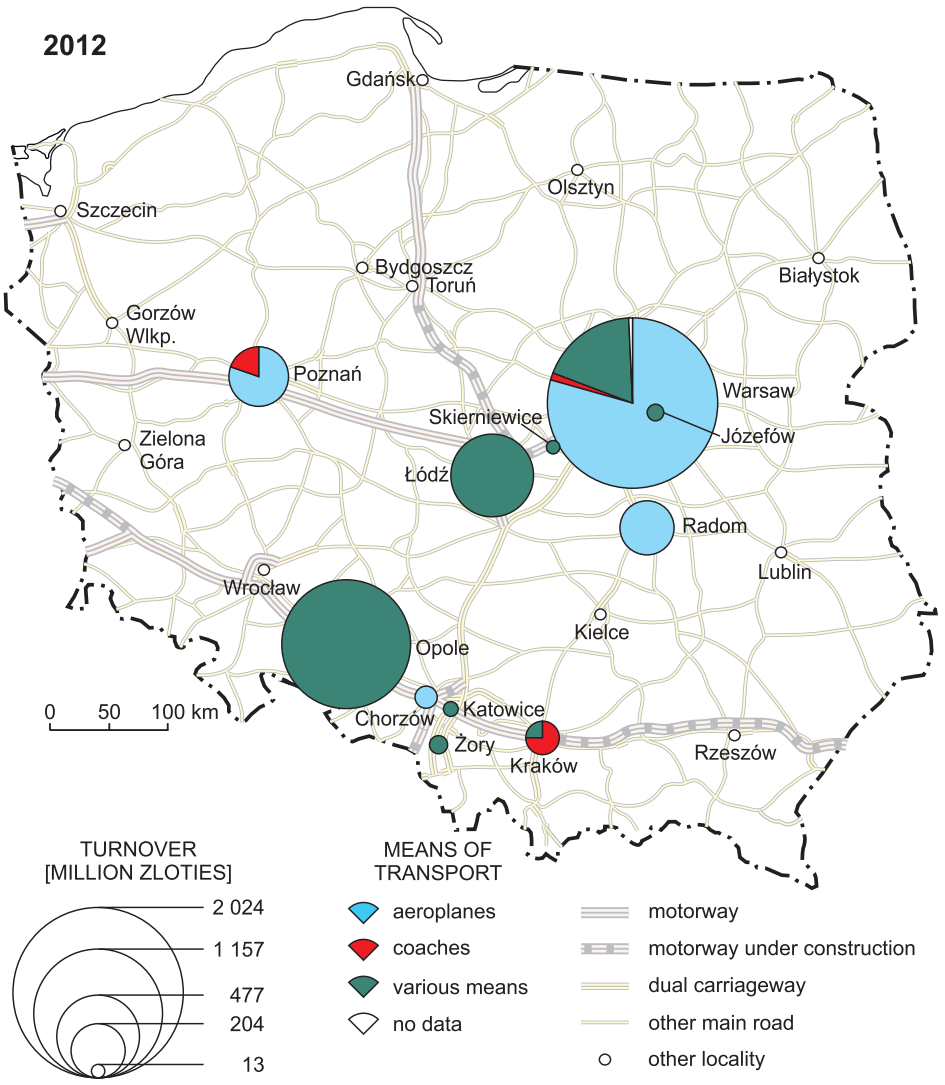

Figure 2. Tour-operator structure by means of transport and turnover from the organising of tourism

Based on: (1) Touroperatorzy Raport 2012; (2) Touroperatorzy Raport 2013; (3) www.infoveriti.pl; (4) websites of tour-operators. 
are concerned, aeroplanes again dominate $(80 \%)$, while in Kraków the situation is quite different, with coaches on $75.2 \%$. In the case of the tour operators whose seats are located elsewhere, only one category of means of transport is used. In the cities of Opole, Łódź, Żory, Katowice and Józefów, it is 'various means of transport' that are involved, while in the cities of Radom and Chorzów - aeroplanes (Fig. 2).

\section{Passenger carriers in the servicing of Polish tour operators}

"An important feature of the technological conditions underpinning the service activity in carriage is a high share of fixed costs in total costs, or otherwise a high ratio of constant to floating costs" (Konieczna-Domańska 2008: 47). This is true of all means of transport. As has already been mentioned, in an absolute majority of tourist events organised by the Polish tour operators, aircraft are used as the primary, along with possibly one or more other means of transport. In mass tourist traffic, organised by the largest tour operators, flights take place mainly as charters. Barrett estimates the charter product's costs "to range between 32 per cent and 37 per cent of the costs of the traditional scheduled airline product" (Barrett 2008: 104). The cascade analysis undertaken earlier by Doganis $(2006,2010)$ confirms the costs incurred by charter airlines as much lower than an FSC and even an LCC on the same route. Tour operators above all organise standard tours to popular localities on terms of inclusive tours - flight packages organised with the use of a special discount fare available for this type of travel only. It can therefore be said, with a degree of simplification, that charter flights serve organised mass foreign outward tourism almost exclusively, while - on the other hand - not all tourist flights are performed as charters; it is estimated that about $90 \%$ of all participants of tourist events use charter flights (leaving aside customers' own access, for example by car or plane).
A quite different situation applies to scheduled air traffic, including low-costs ${ }^{5}$. Scheduled flights relate to various goals and purposes of travel, like gainful employment, business trips, family visits and individual tourism, and only to some extent do they concern mass organised tourist traffic. To a greater extent, scheduled flights are used by smaller tour operators, directed to special segments of the market, which may be unable to fill an aircraft or even the greater part of one. In such situations it may even happen that participants from a small group event buy air tickets on their own, individually. Network carriers are also used by larger tour operators, but it is not easy to determine the level of intensity of this cooperation. Thus, despite quite good statistics on scheduled air traffic, data on this are concerned to only a limited extent with organised tourist traffic, while domestic traffic does not concern it at all. Therefore, in what follows, scheduled traffic will be described briefly, while foreign charter traffic will be presented more extensively. It should nevertheless be recalled that charter flights can also be provided by network (scheduled) carriers, including low-costs. By and large, a common feature of air carriers is their great variety in cooperation with tour operators.

In 2012, Polish airports served a total of 24.6 million passengers, including 3.6 million in domestic, and slightly more than 21 million in international traffic. These numbers do not encompass certain departures organised by the Polish tour operators, but using Czech or German airports located near the southern and western borders, especially in flights heading for the Mediterranean. Unfortunately, there are no statistics available in relation to this phenomenon. The structure of the traffic at Polish airports, as divided into FSCs, LCCs, charters and others, is given in Figure 3.

\footnotetext{
${ }^{5}$ Low-cost carriers are a reflection of the liberalisation of air transport. There is a great and growing literature on this subject (cf. Williams 2001; Dobruszkes 2006, 2009, 2013; Doganis 2006, 2010; Francis et al. 2006; Barrett 2008; Graham \& Shaw 2008; Graham 2013; Wu \& Hayashi 2014, for example).
} 


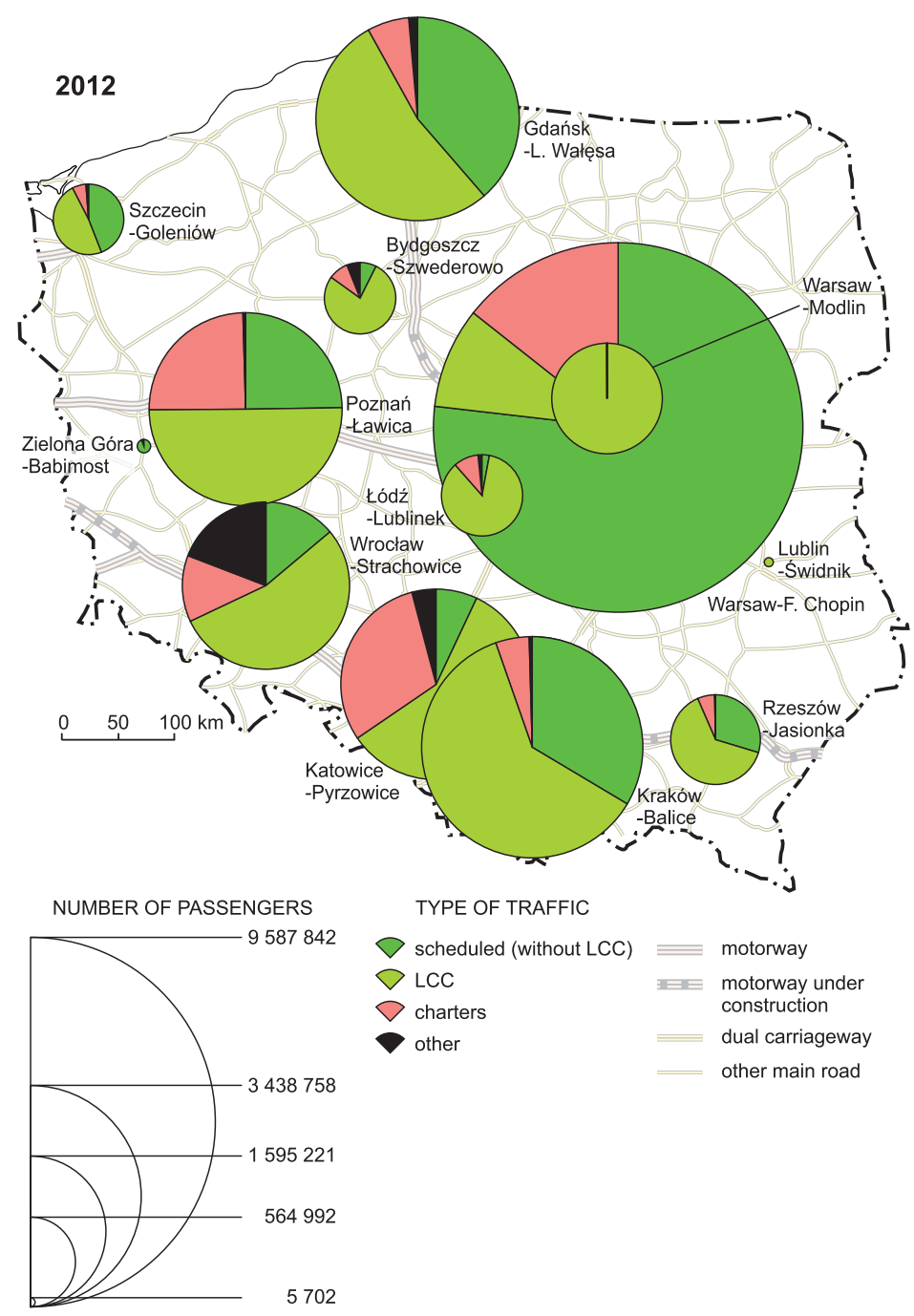

Figure 3. Airports in Poland - structure by numbers of passengers served and type of traffic Based on: (1) Polskie Porty Lotnicze. Raport roczny 2012; (2) www.airport.lublin.pl (18 February 2014); (3) data of Łódź Airport.

\section{Air scheduled carriers}

According to data from Poland's Civil Aviation Authority, an absolutely predominant share of the network airline services on the Polish market is taken by just 25 carriers, which together serve some $98.7 \%$ of all passengers (Table 1). However, cooperating tour operators could not be found in the case of every carrier, since, as has already been noted, scheduled carriage serves various purposes, and not first and foremost the servicing of organised tourist traffic.

Amongst the larger network carriers are LOT Polish Airlines with its affiliate EuroLOT, which jointly serve $29.1 \%$ of passengers and cooperate with many of the largest tour operators (e.g. Itaka, Rainbow Tours, Neckermann Polska and Exim Tours), as well as smaller ones. Given the most important direction of flights (the UK, Ireland, Germany and Norway), the 
Table 1. Passengers served at Polish airports by way of scheduled air traffic, by carrier (as of 2012)

\begin{tabular}{|l|r|r|}
\hline \multirow{2}{*}{ Carrier } & \multicolumn{2}{|c|}{ Passengers } \\
\cline { 2 - 3 } & Number & Percentage \\
\hline LOT Polish Airlines + EuroLOT & $6,175,015$ & 29.10 \\
Ryanair & $4,887,084$ & 23.03 \\
Wizz Air & $4,185,392$ & 19.72 \\
Lufthansa & $1,500,875$ & 7.07 \\
OLT Express Regional & 687,498 & 3.24 \\
easyJet & 429,071 & 2.02 \\
Norwegian Air Shuttle & 375,644 & 1.77 \\
Air France & 330,631 & 1.56 \\
SAS & 290,967 & 1.37 \\
EuroLOT & 265,794 & 1.25 \\
KLM Royal Dutch Airlines & 232,697 & 1.10 \\
Swiss International Air Lines & 176,509 & 0.83 \\
British Airways & 167,662 & 0.79 \\
OLT Express Poland & 164,202 & 0.77 \\
Aeroflot-Russian Airlines & 160,649 & 0.76 \\
Austrian Airlines & 153,007 & 0.72 \\
Aer Lingus & 132,648 & 0.63 \\
Finnair & 126,064 & 0.59 \\
Air Berlin & 95,144 & 0.45 \\
Alitalia & 83,164 & 0.39 \\
Czech Airlines & 73,201 & 0.34 \\
Turkish Airlines & 65,058 & 0.31 \\
TAP Portugal & 64,000 & 0.30 \\
Brussels Airlines & 59,845 & 0.28 \\
Aerosvit Airlines & 59,229 & 0.28 \\
Other carriers & 280,380 & 1.32 \\
\hline & & \\
& & \\
\hline
\end{tabular}

Source: www.ulc.gov.pl/pl/regulacja-rynku/324-statystyki-i-analizy (10 February 2014), Poland's Civil Aviation Authority (ULC).

second-largest scheduled carrier - the Irish low-cost Ryanair, first and foremost caters for gainful-employment trips, rather than those based around tourism. Another low-cost, the Hungarian Wizz Air, serves both segments of the market and cooperates with several tour operators (Itaka, Rainbow Tours, Otium Polska, Espace Trans and Pol Tur $)^{6}$. Finally, the fourth

\footnotetext{
${ }^{6}$ An obvious advantage of LCCs over charters is the possibility of flexible manipulation of the length of a person's stay, as well as more opportunities for the selection of times, including those without charter flights. Thus, some tour operators (e.g. Neckermann
}

most significant carrier on the Polish market - the full service carrier Lufthansa - in fact offers various kinds of carriage, including of tourists, and at times in cooperation with certain Polish tour operators.

Taking into account the numbers of passengers of network airlines, the Polish carriers (mainly LOT Polish Airlines + EuroLOT, OLT Express Regional, EuroLOT and OLT Express

Polska, Ecco Holiday) have in their offer proposals anticipating customers' own arrivals, considering cooperation with the low-costs, and what is more, at attractive prices. 
Poland) together served $34.6 \%$ of passengers. In turn, the share of low-cost carriers in scheduled traffic in Poland in 2012 was 47.4\%. This is the result of the activity of such LCCs as Ryanair, Wizz Air, easyJet, Norwegian Air Shuttle and Air Berlin, as well as several smaller lines not mentioned in Table 1.

\section{Air charter carriers}

While scheduled air traffic participates in the servicing of the Polish market to some unidentified extent only, charter traffic serves foreign tourist flights almost exclusively. The difference between the number of all passengers on charter flights and flights in international traffic is of 128,515 people. The difference reflects commissioned flights, flights for firms, as well as the necessity for the supplying/retrieval of some participants of excursions to/from hubs prior to departures abroad. The charter market is extremely seasonal, with a maximum during the summer holidays (July-September) and a minimum in winter. The charter market is also very much differentiated, and characterised by variations in operations and ownership. The majority of charter carriers are in private hands.

Table 2. Passengers served at Polish airports by way of charter traffic, by carrier (2012)

\begin{tabular}{|c|c|c|}
\hline \multirow{2}{*}{ Carrier } & \multicolumn{2}{|c|}{ Passengers } \\
\hline & Number & Percentage \\
\hline Enter Air & 981,698 & 30.54 \\
\hline Travel Service a.s. & 587,492 & 18.28 \\
\hline Small Planet Airlines & 239,539 & 7.45 \\
\hline OLT Express Poland & 188,577 & 5.87 \\
\hline Travel Service Polska & 184,457 & 5.74 \\
\hline Bingo Airways & 173,274 & 5.39 \\
\hline LOT Polish Airlines + EuroLOT & 101,638 & 3.16 \\
\hline Nouvelair & 101,037 & 3.14 \\
\hline Pegasus Airlines & 91,261 & 2.84 \\
\hline SprintAir & 84,916 & 2.64 \\
\hline Air Cairo & 84,344 & 2.62 \\
\hline Nesma Airlines & 54,633 & 1.70 \\
\hline Sky Airlines & 47,144 & 1.47 \\
\hline Corendon Airlines & 30,647 & 0.95 \\
\hline YES Airways & 28,674 & 0.89 \\
\hline Bulgarian Air Charter & 26,446 & 0.82 \\
\hline Aegean Airlines & 18,583 & 0.58 \\
\hline Arkia Israeli Airlines & 18,499 & 0.58 \\
\hline Freebird Airlines & 13,450 & 0.42 \\
\hline El Al Israel Airlines & 12,135 & 0.38 \\
\hline Air Arabia & 10,965 & 0.34 \\
\hline Israir Airlines & 10,018 & 0.31 \\
\hline Onur Air & 8,968 & 0.28 \\
\hline Syphax Airlines & 7,590 & 0.24 \\
\hline Thomas Cook Airlines & 4,858 & 0.15 \\
\hline Other carriers (101) & 103,284 & 3.21 \\
\hline
\end{tabular}

Source: www.ulc.gov.pl/pl/regulacja-rynku/324-statystyki-i-analizy (10 February 2014), Civil Aviation Authority (ULC). 
According to ULC data, a dominant share among charter lines on the Polish market is taken by 25 carriers, which serve $96.8 \%$ of all passengers (Tab. 2). The remaining 3.2\% of passengers are served by as many as 101 charter carriers, sometimes very exotic: it may be supposed that the cooperation between tour operators and these firms is of a more incidental nature, not being based around permanent agreements at least. Unlike with scheduled air traffic, in an absolute majority of cases it has been possible to determine which tour operators collaborate with which charter carriers.

The largest share among the charter carriers is that taken by the private Polish airline Enter Air, which serves more than 30.5\% of all passengers and cooperates with at least 16 large tour operators. What is of interest is that a turnover of some 750 million zloties is achieved on the basis of a fleet consisting of just 12 aircraft. Besides the Polish market, the line is also present in France (with a base at Paris-Charles de Gaulle Airport), in the Czech Republic (Prague Ruzyně Airport), and to some extent also in Italy and Spain. Annually, Enter Air carries about 1.5 million passengers, including 981,698 on connections to/ from Poland.

A large share in the servicing of the Polish charter market (18.3\%) has been taken by the Czech-based private carrier Travel Service, as well as its affiliate Travel Service Polska (5.7\%). The two carriers cooperate with a dozen or so tour operators but - interestingly - each deals with a different set. The Lithuanian private charter carrier Small Planet Airlines also takes a substantial share (7.5\%) in the servicing of passengers in Poland. Active for several months only, OLT Express Poland carried 5.9\% of all passengers in 2012, while the other private Polish airline - Bingo Airways - took 5.4\%. Alongside scheduled services, charter flights are also provided by stateowned LOT Polish Airlines, jointly with its affiliate EuroLOT (with the two combined taking a $3.2 \%$ share). The list of the largest charter operators, transporting over 100,000 people, is completed by the Tunisian Nouvelair. The remaining smaller charter carriers are mainly from reception countries, such as Egypt, Turkey, Greece, Bulgaria, Israel and the United Arab Emirates.

As may already be seen, it is charter carrier airlines from Central and Eastern Europe that prevail here, Polish companies most of all. The Polish carriers' share is $61.8 \%$ of passengers, and this is of course a much higher figure than was observed in the case of the scheduled flights. This is mainly a result of Enter Air, OLT Express Poland, Travel Service Polska, Bingo Airways, LOT Polish Airlines + EuroLOT, SprintAir, and YES Airways.

Data provided on a webpage of the ULC, used in conjunction with a report entitled Loty czarterowe z Polski - lato 2012 (www.tanie-loty.com.pl) allow considerable familiarity with the main directions of charter flights from/ to Poland to be gained. Where do Polish tourists using international charter connections within mass organised tourist traffic fly? Like travellers from other parts of Europe, they mainly take charter flights from Poland in a southerly direction, to the Mediterranean, Red Sea, Black Sea and Canary Islands. The largest flows of tourists lead to the Egyptian Hurghada and Sharm el-Sheikh, as well as Turkish Antalya (Tab. 3, Fig. 4). Such a concentration of passenger charter flights probably reflects the choice of sun, sea and sand destinations, and also offering competitive prices.

The remaining several percent of passengers on charter flights from Poland have other resorts located within the same geographical area. In the eastern part of the Mediterranean one can distinguish Heraklion (Iraklion) on Crete, Tel-Aviv, Greek Rhodes and Kos and Turkish Bodrum. In the western part of the Black Sea the main destinations are Bulgarian Burgas and Varna, and on the coast of the Red Sea (apart from Hurghada and Sharm el-Sheikh), the relatively new centre of Marsa Alam. On the southern coast of the Mediterranean it is Enfidha and Monastir in Tunisia that dominate, and, in the west, Palma de Mallorca and Barcelona. Finally, a last concentration embraces the Canary Islands and Moroccan 
Agadir. More important destinations on the Canary Islands are Fuerteventura and Tenerife, while more minor ones are Las Palmas and Lanzarote. The main directions taken by charter flights point explicitly to the domination of typical leisure trips where mass organised tourist traffic is concerned.

In the case of charter flights, it is even possible to determine some dependent relationships of a statistical nature. Thus, between the number of passengers transported by individual carriers (25) offering charter flights from/ to Poland and the number of participants in tourism organised by the top 38 Polish tour operators, there is a linear relationship assuming the form:

$$
y=2.056312 x-39924.794767
$$

where $x$ is the number of participants in instances of tourism,

$y$ is the number of charter-flight passengers. The linear regression model obtained achieves statistical significance, with a correlation coefficient of $r=0.9559119$, and a determination coefficient $r^{2}=0.9156804$.

Table 3. Passengers served at Polish airports on international charter flights, as categorised by destination (2012)

\begin{tabular}{|l|r|r|}
\hline \multirow{2}{*}{ Destination } & \multicolumn{2}{|c|}{ Passengers } \\
\cline { 2 - 3 } & Number & Percentage \\
\hline Hurghada & 416,575 & 13.15 \\
Antalya & 399,637 & 12.62 \\
Sharm el-Sheikh & 268,590 & 8.48 \\
Enfidha & 143,956 & 4.55 \\
Heraklion (Iraklion, Crete) & 128,210 & 4.05 \\
Fuerteventura & 120,657 & 3.81 \\
Tel-Aviv & 110,722 & 3.50 \\
Burgas & 102,114 & 3.22 \\
Rhodes & 98,489 & 3.11 \\
Tenerife & 98,274 & 3.10 \\
Bodrum & 87,285 & 2.76 \\
Marsa Alam & 72,540 & 2.29 \\
Palma de Mallorca & 68,806 & 2.17 \\
Kos & 60,856 & 1.92 \\
Chania (Khania, Crete) & 55,643 & 1.76 \\
Monastir & 53,217 & 1.68 \\
Varna & 52,754 & 1.67 \\
Dalaman & 51,013 & 1.61 \\
Kerkyra & 49,996 & 1.58 \\
Izmir & 47,806 & 1.51 \\
Zakynthos & 45,555 & 1.44 \\
Las Palmas & 44,939 & 1.42 \\
Agadir & 39,216 & 1.24 \\
Lanzarote & 38,224 & 1.21 \\
Barcelona & 36,398 & 100.00 \\
Other airports & 475,500 & \\
Total (international traffic) & $3,166,972$ & \\
\hline
\end{tabular}

Source: www.ulc.gov.pl/pl/regulacja-rynku/324-statystyki-i-analizy (10.02.2014), Civil Aviation Authority (ULC). 


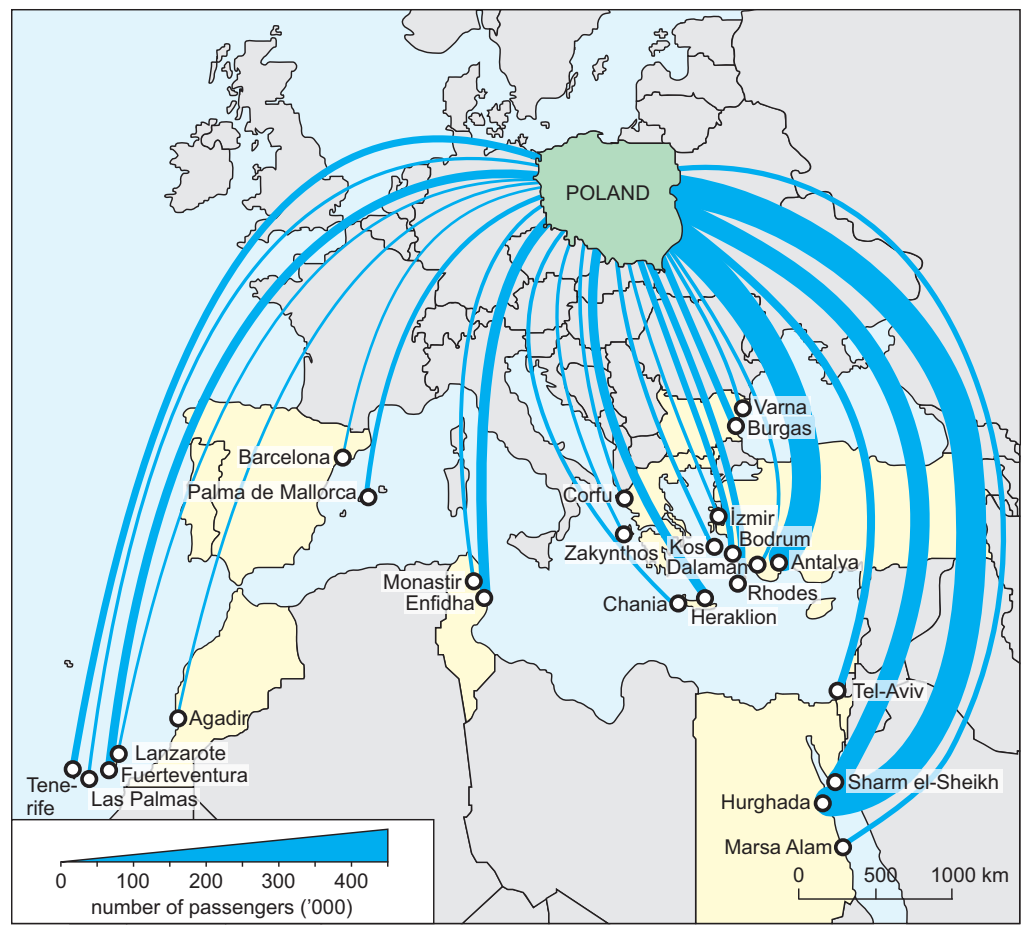

Figure 4. Main destinations of charter flights from Poland by numbers of passengers carried Based on: www.ulc.gov.pl/pl/regulacja-rynku/324-statystyki i analizy (18 February 2014).

\section{Road carriers}

Coach is the second most-used means of transport among the tour operators researched. It was even more typical for coaches to be made use of in the 1990s, but with increased affluence in Polish society, and a partial change in the nature of foreign outward travel from touring excursions (sightseeing) to typical leisure (holiday) tours, the role played by coaches has been in gradual decline. Coaches are used, first and foremost, in closer relations, particularly in travel connected with skiing (e.g. in the Alps and Dolomites), and partly also during circular excursions (Central and Eastern Europe, Southern Europe).

Data concerning road carriers and cooperating tour operators are less readily available than those concerning air carriers. It is most frequently the case that road carriers are small firms, employing just one or several people, and sometimes having just a single coach, and so working on an ad hoc basis, in line with actual needs, without any fixed agreements on cooperation with tour operators.

The largest coach carrier is Sindbad, which besides scheduled international coach carriage, also has an involvement in outward and inward tourism, and in the leasing of coaches. Tour operating is in this case an additional activity. Employment (405 people) and size of own fleet (95 coaches) and number of leased coaches (21) also leave Sindbad in an exceptional position. The remaining coach carriers searched have markedly smaller fleets and employ fewer workers, despite the fact that some engage in a wide profile of relevant activities.

Some carriers' activities are limited to the leasing of coaches, while others in addition organise their own tourism, engage in scheduled coach carriage, or provide transfers to airports, even foreign ones (e.g. to Berlin). 
As can already be seen, some coach carriers providing services for the largest Polish tour operators also offer tourist services under own brands, either by way of brokerage as regards someone's else tourism, or by organising instances of tourism of their own (like excursions for schools or factories).

All road carriers are private companies. Nevertheless, firms possess quite large fleets of vehicles, sometimes built up over many years. Carriers usually employ from 10 to 30 workers (an exception is the aforementioned Sindbad), while fleets mostly consist of several up to 40 vehicles (again an exception is $\operatorname{Sindbad}$ ). A portion of coach carriers cooperate constantly with selected tour operators, but this is rather a minority of cases, as has been mentioned before. The seats of the largest coach carriers are spread throughout the country, with a slight concentration in the southern part of the country. In the case of Krakówbased tour operators, one can in any case observe the tendency to use local coach carriers.

Some tour operators have a fleet of coaches at their own disposal to transport own customers and possibly also those of competitors. Thus, some tour operators use own coaches only, to a large extent these are tour operators engaged in incoming tourism. Moreover, an own fleet is characteristic for tour operators with capital of Polish origin only. The largest tour operators with foreign capital or with 'mixed' Polish and foreign capital as a rule do not have their own fleet of coaches, though in their offer it is possible to find tourism associated with tourists' own access (ski-tours, typical summer holidays).

Some tour operators (e.g. Itaka, Rainbow Tours, Centrum Turystyki Oskar, Almatur Opole, Lekier, Sigma Travel) own a fleet

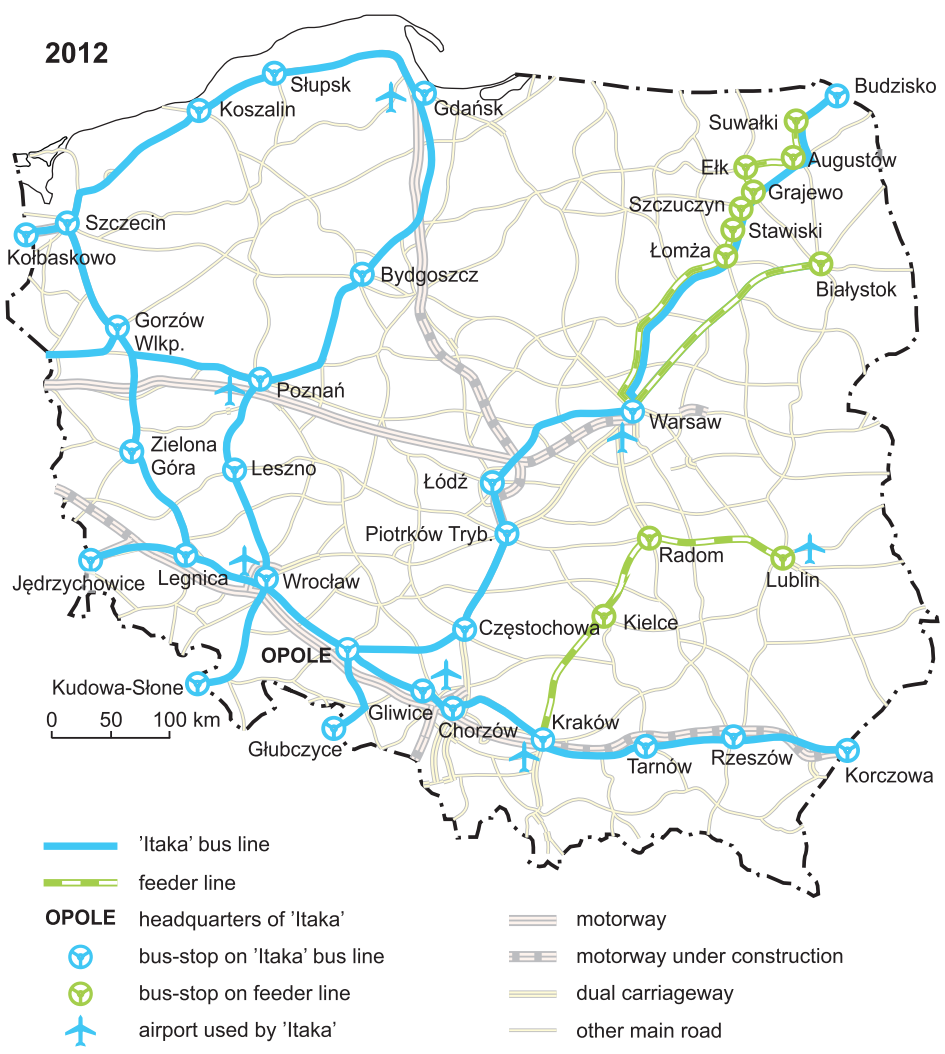

Figure 5. The network of coach connections and airports serving Itaka tours 
of coaches, but also use leased vehicles. Therefore, they try to have a certain flexibility allowing them to react properly to possible changes in demand for carriage, without the necessity of maintaining a large fleet of vehicles. In the case of a group of companies such as Almatur, for example, one can note the usage of vehicles of other entities that nevertheless belong to the same group.

In the light of growing competition, and with a view to achieving better spatial penetration of the market, some tour operators are introducing so-called 'feeder' bus lines. These are conceived as allowing access for tourists inhabiting smaller localities, away from the largest urban centres, to reach the hubs in the form of the larger towns, cities and/or airports. For example, the largest Polish tour operator (Itaka) uses contracted private microbuses and coaches to carry tourists to hubs, and once a trip has ended, travellers depart back for their places of origin. Tourists can start and finish their trips at localities along the route and at border crossing points, too. In turn, main routes are served by Itaka. In this way tour operators penetrate a large portion of Poland's territory (Fig. 5).

\section{Other carriers}

The remaining means of transport are used only occasionally by the analysed top 38 tour operators. Only some of these provide information on the usage of other means of transport besides aeroplanes and/or coaches during organised instances of tourism.

In Poland, maritime tourism cannot be qualified by the adjective 'mass', though it is a fast-developing segment of the market, and certain offers are to be found amongst selected tour operators (e.g. Atlas Tours, Sigma Travel, Itaka, Rainbow Tours, TUI Poland). When it comes to cruising excursions, tour operators offer help with the organisation of individual and group travel, including in the context of team building, but also offers packages that entail cruising, as well as the journey to/from the seaport(s) of embarkation and disembarkation by coach or plane. On offer is the sale of trips, mainly to the Mediterranean and Black Seas, Northern Europe and the Baltic Sea, and to a lesser extent also exotic destinations such as Hawaii, Florida, The Bahamas, or the Caribbean Sea, with the Gulf of Mexico, Alaska, Canada and the Sawyer Glacier, or East Asia. Some tour operators use scheduled ferry links on the Baltic Sea, around the Canary Islands archipelago, on the Croatian coast, or from Italy to the nearby islands, to Skye, via the English Channel. Also a sail down the Nile is on offer from some tour operators.

Railways are only very seldom used as means of transport by Polish tour operators, and this is rather the case abroad than in Poland. Scheduled trains feature in the offer from Itaka (the TGV for a transfer from the city of Nice to Cannes, the Trans-Siberian Railway from Irkutsk to Listwinka, or the Shinkansen on the Fukuoka-Hiroshima route). Also highspeed and conventional railways are used in China, as are heritage steam railways in India. Rainbow Tours, in sending coach excursions from the Continent to the UK (besides ferries) also offers trains via Eurotunnel. Overnight transfers by scheduled trains are in the excursion offer of Alfa Star and TUI (on the Aswân-Cairo tour). In China, on the Beijing$X^{\prime}$ ian route an overnight journey is on offer from TUI.

Some tour operators (e.g. TUI Poland) that make use of foreign airports provide their customers with free tickets for train access to any airport in Germany in the context of a service called rail\&fly. It is not important which the departure airport is, since the journey to the airport is offered to tourists free. This is also true of the transfer from railway station to airport. All this is on the basis of an agreement between TUI and Deutsche Bundesbahn, 12 local rail carriers (i.a. Regional Bahn, Stadt Express, Regional Express, S-Bahn) and the VDV Union of Regional Carriers (U-Bahn, buses and trams taken together). Together with travel documents, tourists receive a rail ticket valid for 48 hours before and after the tour. Such a solution is particularly advantageous 
for inhabitants of western Poland who live closer to Berlin or Dresden than to Warsaw?.

Railways, besides their utilitarian function of carrying scheduled traffic of trains used in tourism, can also serve in the capacity of primary or supplementary tourist attraction. In Poland, despite the existence of 37 tourist railways, including 28 entities carrying traffic on narrow-gauge lines, rail tourism is a relatively new phenomenon, and not therefore very common (Bebenow 2015). The most common form of response to tourist needs is to make heritage railways available for visitors, while usage of rail as a means of transport is frequently connected with a necessity to revitalise railways.

\section{Summary and Conclusions}

An analysis which focuses on the 38 largest Polish tour operators, as well as air carriers and major coach operators cooperating with them, made it possible to put forward the following conclusions.

A hierarchy of the largest tour operators and the largest air and road carriers has been created during the analysis. By and large, where the turnover of a tour operator is greater, so also is the number of cooperating carriers, and the variety of means of transport being used. However, the largest tour operators first and foremost utilise aeroplanes and/or coaches. Other means of transport, such as cruise liners, sea ferries, or railways, are used only occasionally, if at all, despite the enormous potential for their usage in mass organised tourist traffic.

Information on the tour operators and their various carriers confirms the extreme pricesensitivity of the Polish tourist market, and thus accounts for the great popularity of the cheapest charter carriers coming on to the market and seeking to draw immediate attention with their lower fares. As Martín et al. (2008: 214) write, "many leisure travellers are likely to choose the lowest-priced carrier,

\footnotetext{
7 Intermodal agreements between airlines and rail operators offer a number of potential advantages for all participants (cf. Givoni \& Banister 2006; Chiambaretto \& Decker 2012).
}

regardless of service quality". This is a substantial difference found when Poland is compared with more affluent societies of Western and Northern Europe, in which low-cost carriers play a much greater role in carriage to leisure centres in the Mediterranean area.

Statistically significant linear regression models have been established for the relationships: (1) between turnover resulting from the organisation of tourism and the number of customers of individual tour operators; and (2) between the numbers of passengers taken by individual charter air carriers and the numbers of participants in instances of tourism organised by tour operators headquartered in Poland. The other linear regression models computed, despite manifesting obvious dependent relationships, did not achieve statistical significance.

In 2012, the analysed tour operators mainly made use of the services of some 50 air carriers (charter and scheduled), even if the potential list is much longer. The number of registered charter carriers alone is 126 , but collaboration with a large number has been on an occasional basis at best. It is apparently usual for carrier companies to hail from Central Europe or the Mediterranean basin area, though in not all cases (especially with scheduled traffic) could the airlines cooperating with individual tour operators be confirmed. Of much greater credibility is the information on cooperation between tour operators and charter carriers.

In Poland, there are five registered air carriers that engage in the servicing of tour operators, including four 'native' companies (LOT Polish Airlines with its affiliate EuroLOT, Enter Air, Bingo Airways and SprintAir, not to mention YES Airways incorporated by OLT Express Poland, which together with OLT Express Regional went bankrupt in mid-2012), plus one company that is an affiliate of the Czech network and charter Travel Service a.s. operator (Travel Service Polska). However, the share of carriage accounted for by the Polish operators is disproportionately larger: at $34.6 \%$ among the network carriers, and $61.8 \%$ among the charter carriers. 
The largest air carrier serving Polish tour operators is LOT Polish Airlines, which provides scheduled and charter flights. Other home carriers in practice limit their activities to charter flights. The largest of these is Enter Air, with its fleet of 12 passenger aircraft. The remaining companies play a much more limited role, with fleets not exceeding 5 aeroplanes. Moreover, the segment of charters is seen to be under continuous transformation.

Polish air carriers other than the flag LOT Polish Airlines are wholly privately-owned. LOT is a company with a long tradition (founded 1929), but the majority of Poland's private charter carriers have only recently been present on the market. The presence of separate viable, or even vibrant air charter companies not being a part of large tour operators seems to be something of a regional speciality. This is in contrast to the vertical integration occurring in many Western European countries, for example (Buck \& Lei 2004).

Large international tour operators (e.g. Neckermann Polska of the Thomas Cook Group) have their own airlines (Thomas Cook Airlines, Condor Airlines, etc.). They use these in achieving their own objectives, but also make them available to competing tour operators. Sometimes they own, not only an air carrier, but also shares in other transport companies (capital links of TUI with Air Berlin, for example). On the Polish market we also observe airlines belonging to tour operators that are not directly engaged more widely in other activity (e.g. Globalia Tourism, Gropo Iberostar and Balkan Holiday).

The Polish tour operators requiring charter flights mainly utilize domestic carriers, as well as one or two significant ones from neighbouring countries (the Czech Republic and Lithuania). Moreover, it is quite common for use to be made of air carriers in reception countries (Turkey, Tunisia, Egypt, Israel, Greece and Bulgaria). Beyond Europe and the Mediterranean Basin, the only significant charter carrier is the low-cost Air Arabia seated in the United Arab Emirates.

There are also charter flights of the LCCs (Turkish Corendon Airlines and Onur Air, and the already-mentioned Air Arabia), but this is not a frequent phenomenon. At least some scheduled low-costs take part on a limited scale in the servicing of organised tourist traffic (e.g. Wizz Air, easyJet and Norwegian Air Shuttle), this reflecting their servicing of other segments of the market. Moreover, they fly mainly in an east-west direction (Dobruszkes 2009; Pijet-Migoń 2012), and not north-south, as the orientation along which the demand for mass tourist flights is greatest. In this respect a great difference between Western European and Polish markets emerges when comparisons are made, although the situation may change sooner or later. In the case of the more specialised and less 'mass' types of tourism, a quite common practice is the utilisation of scheduled airlines. The carrier is then adjusted to the size of the group on the basis of actually available seats within the booking system.

In coach transport, three types of activity can be distinguished: tourist travel on 'feeder' lines from smaller localities to hubs using scheduled coaches (sometimes microbuses and cars), carriage of small groups by scheduled coaches, and the usage (sometimes charter) of whole coaches by tour operators (also at destinations).

Some of the tour operators researched have their own coaches at their disposal (e.g. Jan Pol Incoming Tour Operator, Mazurkas Travel, Funclub, Atas and Skarpa Travel). These are put to use in both own carriage and that of the competition. In the case of groups of companies such as Almatur, tour operators not having their own fleets use the coaches of other members of their own group. Own means of transport, if available, are limited to coaches only, and not air carriers. The latter, in turn, is the domain of larger tour operators with foreign capital (TUI, Neckermann), as has been mentioned before.

Tour operators involved in inward tourism usually have their own fleet of coaches (e.g. Jan Pol Incoming Tour Operator, Mazurkas Travel). Possession of an own fleet of coaches is characteristic for tour operators with exclusively Polish capital. As a rule, the largest tour operators with foreign and 'mixed' Polish-foreign capital do not own coaches. 
There is no precise information available on cooperation between Polish tour operators and individual coach carriers. Only a few tour operators provide such information on their websites. This may point to a lack of longterm agreements on cooperation, with carriers being chosen ad hoc, in line with the needs of the given time. Some coach carriers rendering services for the largest Polish tour operators also engage in tourist services under their own brand name, selling someone else's trips, or organising their own instances of tourism. Coaches are used mainly in closer relations, especially in ski-events (e.g. in the Alps or Dolomites), and partly

\section{References}

BarReTt S., 2008. The emergence of the low cost carrier sector [in:] A. Graham, A. Papatheodorou, P. Forsyth (eds.), Aviation and tourism. Implications for leisure travel. Aldershot-Burlington, VT: Ashgate, pp. 103-118.

Bebenow F., 2015. Turystyka kolejowa w Polsce. Poznań: Bogucki Wydawnictwo Naukowe.

BECKEN S., 2005. Towards sustainable tourism transport: An analysis of coach tourism in New Zealand. Tourism Geographies, vol. 7, no. 1, pp. 23-42.

BOWEN J., 2010. The economic geography of air transportation. Space, time, and the freedom of the sky. London-New York: Routledge.

BuCK S., Lel Z., 2004. Charter airlines: have they a future? Tourism and Hospitality Research, vol. 5, no. 1, pp. 72-78.

Chiambaretto P., Decker Ch., 2012. Air-rail intermodal agreements: Balancing the competition and environmental effects. Journal of Air Transport Management, vol. 23, pp. 36-40.

Cornell J., 2008. World cruising routes. London: Adlard Coles Nautical, 6th edition.

Dickinson B., Vladimir A., 2008. Selling the sea. An inside look at the cruise industry. Hoboken, NJ: John Wiley \& Sons, 2nd edition.

Dickinson J.E., Dickinson J.A., 2006. Local transport and social representations: Challenging the assumptions for sustainable tourism. also during circular tours within a sightseeing programme (e.g. in Central and Eastern Europe or Southern Europe).

\section{Acknowledgements}

This research was funded by the National Centre for Science (NCN) project under 2011/01/B/H54/00837.

Editors' note:

Unless otherwise stated, the sources of tables and figures are the authors', on the basis of their own research.

Journal of Sustainable Tourism, vol. 14, no. 2, pp. 192-208.

DOBRUSZKES F., 2006. An analysis of European lowcost airlines and their networks. Journal of Transport Geography, vol. 14, no. 4, pp. 249-264.

DobruSZKES F., 2009. New Europe, new low-cost air services. Journal of Transport Geography, vol. 17, no. 6, pp. 423-432.

DobRUSZKES F., 2013. The geography of European low-cost airline networks: A contemporary analysis. Journal of Transport Geography, vol. 28, pp. 75-88.

Doganis R., 2006. The airline business. LondonNew York: Routledge, 2nd edition.

Doganis R., 2010. Flying off course. Airline economics and marketing. London-New York: Routledge, 4th edition.

Dowling R.K. (ed.), 2006. Cruise ship tourism. Wallingford-Cambridge, MA: CABI.

FORSYTH P., 2008. Tourism and aviation policy: EXploring the links [in:] A. Graham, A. Papatheodorou, P. Forsyth (eds.), Aviation and tourism. Implications for leisure travel. Aldershot-Burlington, VT: Ashgate, pp. 73-82.

Francis G., Humphreys I., Ison S., Aicken M., 2006. Where next for low cost airlines? A spatial and temporal comparative study. Journal of Transport Geography, vol. 14, no. 2, pp. 83-94.

Givoni M., Banister D., 2006. Airline and railway integration. Transport Policy, vol. 13, no. 5, pp. 386-397. 
Graham A., 2013. Understanding the low cost carrier and airport relationship: A critical analysis of the salient issues. Tourism Management, vol. 36, pp. 66-76.

Graham A., Papatheodorou A., Forsyth P. (eds.), 2008. Aviation and tourism. Implications for Leisure travel. Aldershot-Burlington, VT: Ashgate.

GRAHAm B., SHAW J., 2008. Low-cost airlines in Europe: Reconciling liberalization and sustainability. Geoforum, vol. 39, no. 3, pp. 1439-1451.

Gross S., Lück M. (eds.), 2013. The low cost carrier worldwide. Farnham-Burlington, VT: Ashgate.

HALL D.R., 1999. Conceptualising tourism transport: Inequality and externality issues. Journal of Transport Geography, vol. 7, no. 3, pp. 181-188.

HaLL D., 2008. Transport, tourism and leisure [in:] R. Knowles, J. Shaw, I.Doherty (eds.), Transport geographies. Mobilities, flows and spaces. Malden-Oxford-Carlton: Blackwell, pp. 196-211.

IOANNIDES D., 1998. Tour operators: The gatekeepers of tourism [in:] D. loannides, K.G. Debbage (eds.), The economic geography of the tourist industry. A supply-side analysis. London-New York: Routledge, pp. 139-158.

KonieCZnA-DomańsKa A., 2008. Biura podróży na rynku turystycznym. Warszawa: Wydawnictwo Naukowe PWN, 2nd edition.

MAnSFeLd Y., 1990. Spatial patterns of international tourist flows: Towards a theoretical framework. Progress in Human Geography, vol. 14, no. 3, pp. 372-390.

Martín J.C., Román C., Espino R., 2008. Willingness to pay for airline service quality. Transport Reviews, vol. 28, no. 2, pp. 199-217.

Panasiuk A., Pluciński M. (eds.), 2008. Transport morski i lotniczy w obsłudze ruchu pasażerskiego: Implikacje dla regionów. Zeszyty Naukowe, 491, Szczecin: Wydawnictwo Naukowe Uniwersytetu Szczecińskiego.

Peeters P., Szimba E., Duijnisveld M., 2007. Major environmental impacts of European tourism transport. Journal of Transport Geography, vol. 15, no. 2, pp. 83-93.

Pijet-Migoń E., 2012. Zmiany rynku lotniczych przewozów pasażerskich w Polsce po akcesji do Unii Europejskiej. Rozprawy Naukowe Instytutu Geografii i Rozwoju Regionalnego, 25, Wrocław: Uniwersytet Wrocławski.
Polskie Porty Lotnicze. Raport Roczny 2012, www. polish-airports.com/pl/raporty/raporty/raport-roczny-2012-3 [24 August 2014].

Prideaux B., 2000. The role of transport system in destination development. Tourism Management, vol. 21, no. 1, pp. 53-63.

SZYMAŃSKA E., 2009. Biura podróży na rynku usług turystycznych. Białystok: Oficyna Wydawnicza Politechniki Białostockiej, 2nd edition.

TAYloR Z., CIECHAŃSKI A., 2014. Transport companies in the servicing of organised tourism in Poland. Monographs, 16, Warszawa: Instytut Geografii i Przestrzennego Zagospodarowania PAN.

TOUROPERATORZY RAPORT 2012, Wiadomości Turystyczne: Wydanie specjalne - 16 June 2012. Warszawa: Eurosystem.

TOUROPERATORZY RAPORT 2013, Wiadomości Turystyczne: Wydanie specjalne - 16 June 2013. Warszawa: Eurosystem.

Wensveen J.G., 2011. Air transportation. A management perspective. Farnham-Burlington, VT: Ashgate.

WheAtCroft S., 1998. The airline industry and tourism [in:] D. loannides, K.G. Debbage (eds.), The economic geography of the tourist industry. A supply-side analysis. London-New York: Routledge, pp. 159-179.

Williams G., 2001. Will Europe's charter carriers be replaced by "no-frills" scheduled airlines? Journal of Air Transport Management, vol. 7, pp. 277-286.

Williams G., 2008. The future of charter operations [in:] A. Graham, A. Papatheodorou, P. Forsyth (eds.), Aviation and tourism: Implications for leisure travel. Farnham-Burlington VT: Ashgate, pp. 85-102.

Wu C., HAYASH Y., 2014. The effect of LCCs operations and scheduled services deregulation on air charter business in Japan. Journal of Transport Geography, vol. 41, pp. 37-44.

www.airport.lublin.pl - the official webpage of Lublin Airport [18 February 2014].

www.infoveriti.pl - the Info Veriti Polska service making available reports of companies submitted to Krajowy Rejestr Sadowy [5 October 2013, 16 December 2013].

www.tanie-loty.com.pl - the report Loty czarterowe z Polski - lato 2012, tanie-loty. pl Booking Centre [4 February 2014]. 
www.turystyka.gov.pl/ceotipt/statystyki/statystyka/2/ - the official webpage of the CEOTiPT (Central Register of Tourist Agencies and Tourist Brokers) [7 March 2014].

www.ulc.gov.pl/pl/regulacja-rynku/324-statystyki -i-analizy - statistics on the official webpage of the Civil Aviation Authority (ULC) [10 February 2014]. 